\title{
PERMODELAN POLA PERENCANAAN KEUANGAN BERDASARKAN STATUS PERNIKAHAN
}

\author{
Financial Planning Pattern Modelling Based on Marriage Status
}

\author{
Lukmanul hakim $^{1 *}$, Sri Andriani ${ }^{2}$, Nenny Noor Umami ${ }^{3}$ \\ 1,2,3 Program Studi Manajemen, Fakultas Ekonomi dan Bisnis, Universitas Teknologi Sumbawa \\ Jln. Raya Olat Maras, Batu Alang, Sumbawa, NTB, 84371, Indonesia
}

Corresponding authore-mail: ${ }^{* 1}$ lukman.hakim@uts.ac.id

\begin{abstract}
Abstrak
Status pernikahan dalam masyarakat sedikit banyak akan memberikan dampak dalam pengelolaan keuangan. Penelitian ini bertujuan menganalisis perencanaan keuangan berdasarkan status pernikahan dengan variable financial attitude, financial behavior, dan literasi keuangan masyarakat di Sumbawa. Data dianalisis menggunakan Structural Equation Modeling Partial Least Square (SEM-PLS). Hasil analisis dalam penelitian ini menunjukkan bahwa (1) financial attitude berpengaruh signifikan terhadap financial behavior baik status menikah maupun belum menikah, (2) financial attitude memberikan pengaruh signifikan terhadap literasi keuangan baik status menikah maupun belum menikah, (3) financial attitude berpengaruh signifikan terhadap perencanaan keuangan baik status menikah maupun belum menikah, (4) financial behavior berpengaruh tidak signifikan terhadap literasi keuangan baik status menikah maupun belum menikah, (5) financial behavior berpengaruh tidak signifikan terhadap perencanaan keuangan baik status menikah maupun belum menikah, (6) literasi keuangan berpengaruh tidak signifikan terhadap perencanaan keuangan baik status menikah maupun belum menikah, dan (7) Tidak terdapat perbedaan perencanaan keuangan berdasarkan status pernikahan.
\end{abstract}

Kata Kunci : Perencanaan Keuangan; Financial Attitude; Financial Behavior; dan Literasi Keuangan, SEM-PLS.

\begin{abstract}
A Marital status at community can make an impact on financial management. The purpose of this study was to analyze financial planning based on marital status with the variables of financial attitude, financial behavior, and financial literacy towards people who live in Sumbawa. The data were analyzed using Structural Equation Modeling Partial Least Square (SEM-PLS) through smartPLS version 3.0 software. The results of the analysis in this study indicate that (1) financial attitude has a significant effect on financial behavior both based on married and unmarried status, (2) financial attitude has a significant effect on financial literacy both based on married and unmarried status, (3) financial attitude has an effect significant on financial planning based on both married and unmarried status, (4) financial behavior has no significant effect on financial literacy both based on married and unmarried status, (5) financial behavior has no significant effect on financial planning both based on married and unmarried status, (6) financial literacy has no significant effect on financial planning based on both married and unmarried status, and (7) There is no difference in financial planning based on marital status.
\end{abstract}

Keywords: Financial Planning; Financial Attitude; Financial Behavior; dan Financial Literacy, SEM-PLS.

Article info:

Submitted: 22 $2^{\text {th }}$ August $2021 \quad$ Accepted: $25^{\text {st }}$ November 2021

How to cite this article:

L. hakim, S. Andriani, and N. N. Umami, "PERMODELAN POLA PERENCANAAN KEUANGAN BERDASARKAN STATUS PERNIKAHAN", BAREKENG: J. II. Mat. \& Ter., vol. 15, no. 04, pp. 773-784, Dec. 2021.

This work is licensed under a Creative Commons Attribution-ShareAlike 4.0 International License. Copyright @ 2021 Lukmanul hakim, Sri Andriani, Nenny Noor Umami 


\section{PENDAHULUAN}

Selama tiga tahun terakhir masyarakat Indonesia memilih konsumsi yang didasari gaya hidup dan pengalaman yang diperoleh [1]. Survei Badan Pusat Statistik (BPS) mengenai tingkat konsumsi masyarakat pada tahun 2016 juga menunjukkan perubahan pemenuhan kebutuhan masyarakat dari kebutuhan non-leisure ke leisure. Perubahan kebutuhan tersebut menjadi salah satu alasan lambatnya tingkat konsumsi dimasyarakat [2]. Menurut BPS kebutuhan non-leisure merupakan kebutuhan akan makanan dan pakaian, dimana konsumsi akan dua hal tersebut didasari akan kebutuhan pokok. Sedangkan kebutuhan leisure adalah kebutuhan yang meliputi rekreasi dan budaya serta hospitality (hotel dan restoran). Kebutuhan leisure sendiri merupakan suatu kebutuhan yang didasari rasa ingin guna memenuhi kepuasan rohani [2].

Beradasarkan [3], tren pertumbuhan leisure yang diantaranya mencakup restoran dan hotel meningkat sebesar 5,52\% pada kuartal I 2017. Sementara pada sektor konsumsi rumah tangga terus menurun hingga kuartal III 2017. Berbanding terbalik dengan rekreasi dan budaya yang meningkat secara year on year hingga kuartal III 2017. Hal ini mengindikasikan bahwa terjadi peningkatan kebutuhan seseorang untuk memenuhi kepuasan rohaninya. Penelitian sebelumnya oleh [4] mengemukakan bahwa perlu perhatian besar terhadap kaum muda karena rendahnya tingkat literasi keuangannya. Selain itu, faktor sosial-ekonomi dan demografis seperti umur, gender, pendapatan, marital status dan pencapaian pendidikan berpengaruh terhadap tingkat financial literacy pada remaja dan terdapat keterkaitan secara timbal balik antara financial knowledge, financial attitudes and financial behavior. Bahkan menurut [5], tingkat literasi keuangan seseorang yang berasal dari negara berkembang lebih rendah dari pada mereka yang berasal dari negara maju. Oleh karena itu, masyarakat dituntut untuk dapat lebih selektif dan lebih memahami cara mengelola keuangan dengan baik. Dalam pengelolaan keuangan dibutuhkan kemampuan perencanaan keuangan yang baik. Perencanaan keuangan sendiri merupakan proses dalam mencapai tujuan-tujuan financial untuk mempersiapkan kebutuhan atau keinginan di masa yang akan datang [2].

Pada tahun 2013 dan tahun 2016 OJK melakukan survei secara nasional terkait tingkat literasi dan inklusi keuangan masyarakat. Hasil dari survei tersebut menunjukkan bahwa terjadinya peningkatan pemahaman masyarakat terhadap keuangan (well literate) diikuti dengan meningkatnya inklusi keuangan masyarakat berupa keleluasaan terhadap akses produk dan layanan jasa keuangan. Secara nasional meskipun mengalami peningkatan dari tahun 2013 ke tahun 2016 menjadi 29,66\%, literasi keuangan masyarakat Indonesia (well literate) masih cenderung rendah [3]. Masyarakat sekarang menghadapi serangkaian keputusan keuangan yang membingungkan dan berbagai macam produk keuangan. Proses ini menyiratkan bahwa penting bagi rumah tangga untuk memperoleh dan memiliki pengetahuan ekonomi. Namun dalam praktiknya banyak rumah tangga yang mengalami buta huruf finansial, tidak terbiasa untuk membuat keputusan menabung dan investasi yang bijaksana. [6]

Pada perspektif lain, orang yang berstatus menikah, pasangan suami istri yang berkerja guna memenuhi tujuan keuangannya akan saling bergantung satu sama lain. Sehingga perlu direncanakan program untuk meminimalisir resiko bagi pasangan untuk mengurangi tingginya ketergantungan istri terhadap pendapatan suami begitupun sebaliknya. Apabila memiliki beban lain berupa seorang anak, maka keluarga kecil ini harus mengambil keputusan apakah sang istri harus berhenti bekerja dan konsekuensinya adalah istri akan pergantung pada pendapatan suaminya. Oleh karena itu status yang dimiliki seseorang, cendrung menjadi salah satu faktor berbedanya tingkat perencanaan keuangan setiap orang. [7]

\section{METODE PENELITIAN}

\subsection{Financial Attitude}

Keputusan investasi merupakan gambaran dari financial attitude yang dimiliki oleh seseorang sehingga hal ini akan membantu seseorang dalam proses pengelolaan keuangan dan penganggaran keuangan pribadi yang baik [8]. Menurut [9], financial attitudes tercerminkan dalam enam konsep, yaitu: Obsession, pengelolaan keuangan seseorang dilihat dari cara pandang seseorang terhadap uang dan pendapatnya di waktu yang akan datang. Penelitian yang dilakukan oleh [10], menyebutkan bahwa financial attitude memberikan pengaruh pada financial behavior seseorang. seseorang yang mempunyai financial attitude, maka akan memberikan dampak pada baiknya perilaku seseorang dalam mengelola keuangan pribadinya. Sehingga dihipotesiskan sebagai berikut : 
$\mathrm{H}_{1}$ : financial attitude berpengaruh terhadap financial behavior berdasarkan status menikah

$\mathrm{H}_{2}$ : financial attitude berpengaruh terhadap financial behavior berdasarkan status belum menikah

Sifat dalam pengambilan keputusan tersebut didasari oleh unsur obsession (obsesi), power (kekuasaan), effort (usaha), indequecy (kekurangan), retention (penyimpanan), security (keamanan) [9]. Financial attitude atau sikap keuangan merupakan penilaian serta pendapat seseorang mengenai keuangan. Riset oleh [11] dan [12] mengungkapkan bahwa financial attitude memberikan pengaruh pada tingkat literasi keuangan karena dalam menjalankan pengelolaan keuangan setiap keputusan yang diambil akan dipengaruhi oleh sifat yang dimiliki individu tersebut. Individu yang dapat mengelola atau mengontrol keuangannya dengan baik maka akan mempengaruhi literasi keuangannya, sehingga dihipotesiskan sebagai berikut :

$\mathrm{H}_{3}$ : financial attitude berpengaruh terhadap literasi keuangan berdasarkan status menikah

$\mathrm{H}_{4}$ : financial attitude berpengaruh terhadap literasi keuangan berdasarkan status belum menikah

Financial attitude memiliki pengaruh terhadap perencanaan keuangan yang dimiliki, dimana sikap keuangan yang baik akan mendorong perencanaan yang baik pula. Perencanaan keuangan pasti akan dipengaruhi oleh sifat individu tergantung dengan kebutuhan yang akan dipenuhinya [13]. Kebutuhan berdasarkan status juga menjadi salah satu alasan berbedanya perencanaan keuangan setiap orang. Sehingga dihepotesiskan sebagai berikut:

$\mathrm{H}_{5}$ : financial attitude berpengaruh terhadap perencanaan keuangan berdasarkan status menikah $\mathrm{H}_{6}$ : financial attitude berpengaruh terhadap perencanaan keuangan berdasarkan status belum menikah

\subsection{Financial Behavior}

Menabung, membayar hutang tepat waktu, merencanakan masa depan seperti mempersiapkan pension sering dikaitkan dengan manajemen keuangan. Hal ini telah menjadi perhatian semua pihak semenjak tahun 2008 lalu bertepatan dengan terjadinya krisis finansial global terutama terkait sikap dan perilaku seseorang dalam menyikapi penggunaan uang [14]. Financial behavior atau perilaku keuangan adalah gambaran perilaku keuangan seseorang secara aktual [15]. Menurut [15], financial behavior atau perilaku keuangan adalah cara seseorang secara nyata berprilaku dalam memutuskan keuangannya. Financial behavior memiliki pengaruh terhadap literasi keuangan karena pengelolaan keuangan didasari oleh tanggung jawab dalam perilaku individu. Pengelolaan keuangan secara tepat dapat terlihat dari kedisiplinan seseorang mengelola keuangannya, dimana adanya perencanaan keuangan yang matang untuk jangka pendek maupun jangka panjang. sehingga dihipotesiskan sebagai berikut:

$\mathrm{H}_{7}$ : financial behavior berpengaruh terhadap literasi keuangan berdasarkan status menikah

$\mathrm{H}_{8}$ : financial behavior berpengaruh terhadap literasi keuangan berdasarkan status belum menikah

Financial behavior dapat mempengaruhi perencanaan keuangan seseorang. Status yang dimiliki seseorang dapat menjadi alasan berbedanya perilaku keuangan seseorang, sehingga menghasilkan perencanaan keuangan yang berbeda pula [15]. Oleh karena itu dihipotesiskan sebagai berikut:

$\mathrm{H}_{9}$ : financial behavior berpengaruh terhadap perencanaan keuangan berdasarkan status menikah $\mathrm{H}_{10}$ : financial behavior berpengaruh terhadap perencanaan keuangan berdasarkan status belum menikah

\subsection{Literasi Keuangan}

Literasi keuangan diartikan dengan pengetahuan individu memanage keuangannya sehingga tujuannya di masa yang akan datang dapat dicapai. Tujuan yang dimaksud adalah kesejahteraan dan kemandirian keuangan [16]. Literasi keuangan adalah ilmu dan kemampuan dasar yang harus dimiliki oleh seseorang sehingga mampu mengatur keuangan pribadi dengan baik. Ilmu dan kemampuan keuangan yang dimaksud berkaitan dengan keuangan yang termasuk di dalamnya berkaitan dengan pengetahuan yang bersifat mendasar mengenai keuangan pribadi, manajemen keuangan, kredit dan utang, menabung dan melakukan penanaman modal, serta resiko [3].

Menurut [17] tingkat literasi keuangan atau pengetahuan seseorang terhadap ilmu keuangan akan sangat berpengaruh pada perencanaan seseorang terhadap keuangannya. Dengan tersusunnya segala rencana pengeluaran berdasarkan pendapatan yang ia milki diharapkan dapat mengurangi tingkat konsumsi yang tidak diperlukan. Sehingga dihipotesiskan sebagai berikut:

$\mathrm{H}_{11}$ : literasi keuangan berpengaruh terhadap perencanaan keuangan berdasarkan status menikah 
$\mathrm{H}_{12}$ : literasi keuangan berpengaruh terhadap perencanaan keuangan berdasarkan status belum menikah

\subsection{Perencanaan Keuangan dan Status Pernikahan}

"Personal financial planning is the process of managing finances by spending, saving and investing money to live in prosperity, financial independence, and the achievement of financial goals". [18]. Tujuan seseorang tentunya berbeda-beda, namun pada dasarnya untuk mencapai kesejahteraan dan kemandirian finansial. Menurut [19] orang akan mampu merencanakan dan berhasil menusun perencanaan mereka memiliki kecenderungan sebagai orang yang melek financial. Status pernikahan atau status perkawinan merupakan status yang yang dimiliki seseorang secara sah sesuai dengan hukum (adat, agama, negara, dan sebagainya) [20]. Jenis status berdasarkan ketentuan pemerintah menurut BPS, yaitu : 1. Belum menikah, 2. Menikah, 3. Pisah hidup, 4. Pisah meninggal, Berdasarkan jenis-jenis status diatas, maka status pernikahan responden di penelitian ini adalah status pernikahan yang sah secara hukum dan ketentuan yang berlaku di Indonesia [20]. Menurut [7], status seseorang dapat menjadi salah satu faktor yang membedakan perencanaan keuangan seseorang dengan orang lain.

$\mathrm{H}_{13}$ : Terdapat perbedaan perencanaan keuangan seseorang berdasarkan status menikah dan belum menikah

\subsection{Kerangka Pemikiran}

Perencanaan keuangan diperlukan oleh setiap orang tanpa melihat status pernikahan. Perencanaan keuangan yang baik akan membuat seseorang memiliki rencana keuangan masa depan mulai dari belum menikah sampai mempersiapkan pernikahan. Hipotesis di atas digambar pada alur berfikir (kerangka pemikiran) sebagai berikut.

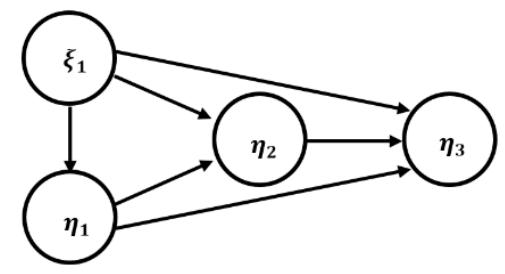

Gambar 3. Kerangka pemikiran penelitian

\subsection{Populasi dan Sampel}

Masyarakat yang berdomisili di Sumbawa yang dibedakan berdasarkan status menikah dan belum menikah merupakan populasi yang digunakan di penelitian ini. Jumlah kemungkinan sampel yang mewakili populasi dalam penelitian ini maka diambil jumlah sampel sebesar 120. Teknik yang digunakan dalam pengambilan sampel penelitian ini adalah metode purposive. Dalam penelitian ini, metode pengumpulan data yang digunakan adalah kuesioner. Dalam penelitian ini 4 skala yang memiliki kriteria sebagai berikut : 4 artinya sangat setuju, 3 artinya setuju, 2, artinya tidak setuju, dan 1 untuk sangat tidak setuju.

\subsection{Structural Equation Model}

Penelitian ini menggunakan metode dan analisis data Struktural Equation Modelling (SEM). Tahaptahap yang harus dilakukan jika menggunakan pastial least square [21]: Langkah pertama dan kedua: merancang inner model dan Outer model. Langkah ketiga: membangun diagram jalur hubungan sebab akibat. Langkah keempat: merubah diagram jalur ke dalam persamaan struktural dan model pengukuran. Langkah kelima: estimasi. Langkah keenam: goodness of fit atau evaluasi model yaitu evaluasi pengukuran dan evaluasi model struktural. Langkah ketujuh: Menguji hipotesis dan menginterpretasikannya.

\subsection{Uji Beda (Independent Sample t-Test)}

Pada penelitian ini juga menggunakan software SPSS 16.0 untuk menguji Independent Sample t-Test. Rumus yang digunakan untuk menghitung Independen t-test dalam penelitian ini yaitu:

$$
t-t e s t=\frac{\bar{X}_{1}-\bar{X}_{2}}{\left(\frac{S D_{1}^{2}}{N_{1}-1}\right)+\left(\frac{S D_{2}^{2}}{N_{2}-1}\right)}
$$




\section{HASIL DAN PEMBAHASAN}

\subsection{Perancangan Inner Model}

Inner model adalah model yang menghubungkan antar konstruk dengan laten. Berikut adalah perancangan inner model dalam penelitian ini:

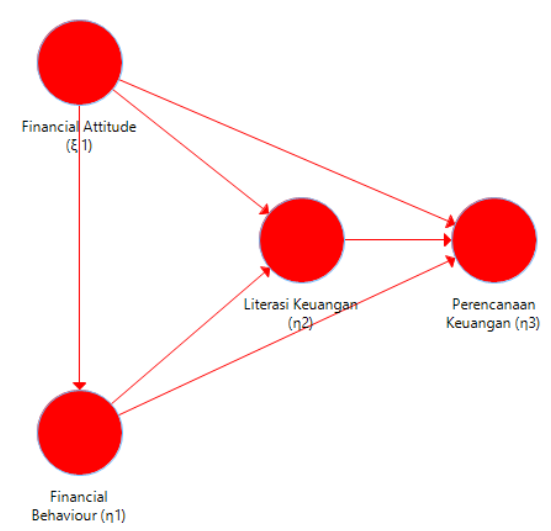

\section{Gambar 4. Perancangan inner model}

\subsection{Perancangan outer model}

Indikator reflektif diasumsikan bahwa konstruk atau konstruk laten memberikan pengaruh pada indikator dengan arah hubungan kausalitas yaitu dari konstruk ke indikatornya atau disebut dengan konsruk manifest [22].

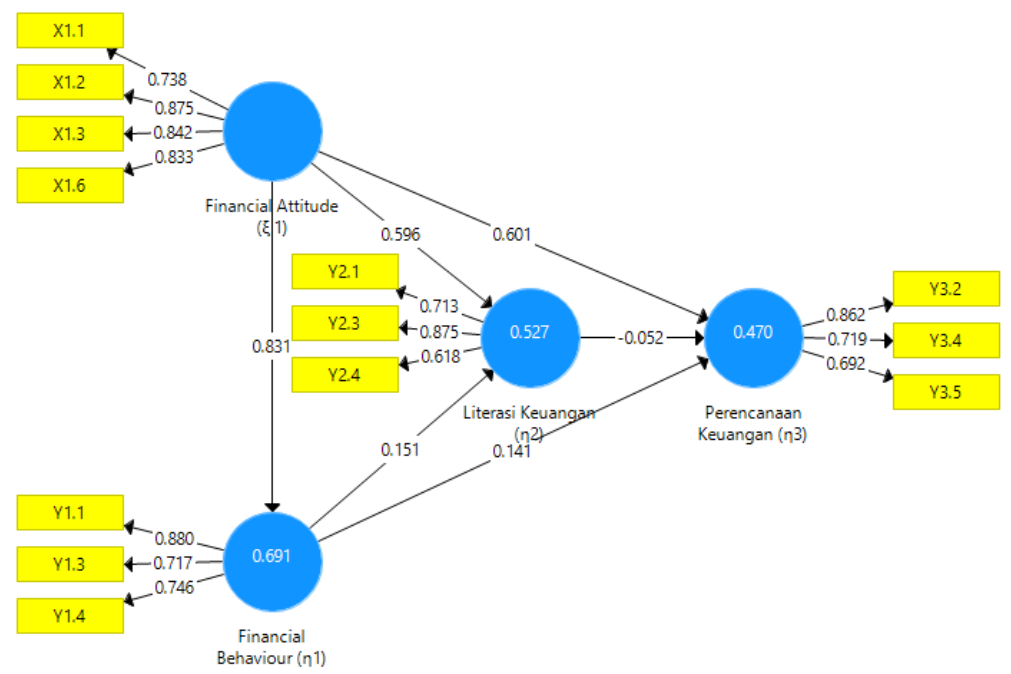

Gambar 5. Output Calculate Algorithm Setelah Modifikasi Status Belum Menikah

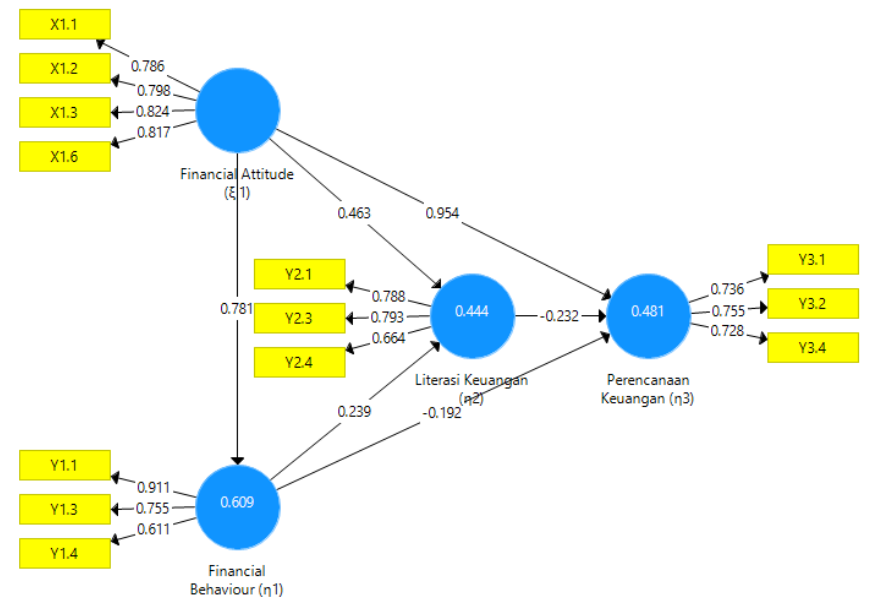

Gambar 6. Output Calculate Algorithm Setelah Modifikasi Status Menikah 


\subsection{Evaluasi Validitas}

Ukuran reflektif dinyatakan tinggi apabila nilai korelasinya $>0.70$ dari nilai konstruk yang ingin diukur. Dalam penelitian tahap awal dari pengembangan skala pengukuran loading sebesar 0,5 sampai dengan 0.6 diangap sudah memenuhi syarat [22]. Oleh karena itu dalam penelitian ini akan digunakan nilai loading sebesar 0.5 .

Tabel 1. Discriminant Validity Status Belum Menikah

\begin{tabular}{llllll}
\hline $\begin{array}{l}\text { Indikato } \\
\mathbf{r}\end{array}$ & \multicolumn{3}{c}{ Konstruk } & Keterangan \\
\cline { 2 - 5 } & $\begin{array}{l}\text { Financial } \\
\text { Attitude }\end{array}$ & Financial Behavior & Literasi Keuangan & Perencanaan Keuangan & \\
\hline X1.1 & 0.738 & 0.684 & 0.595 & 0.516 & Valid \\
\hline X1.2 & 0.875 & 0.726 & 0.680 & 0.587 & Valid \\
\hline X1.3 & 0.843 & 0.699 & 0.555 & 0.522 & Valid \\
\hline X1.6 & 0.833 & 0.623 & 0.533 & 0.614 & Valid \\
\hline Y1.1 & 0.861 & 0.880 & 0.632 & 0.644 & Valid \\
\hline Y1.4 & 0.541 & 0.717 & 0.449 & 0.367 & Valid \\
\hline Y2.1 & 0.443 & 0.746 & 0.379 & 0.328 & Valid \\
\hline Y2.3 & 0.594 & 0.642 & 0.713 & 0.306 & Valid \\
\hline Y2.4 & 0.654 & 0.500 & 0.875 & 0.440 & Valid \\
\hline Y3.2 & 0.616 & 0.392 & 0.618 & 0.294 & Valid \\
\hline Y3.4 & 0.373 & 0.371 & 0.432 & 0.862 & Valid \\
\hline Y3.5 & 0.520 & 0.602 & 0.258 & 0.719 & Valid \\
\hline
\end{tabular}

Indikator $\left(x_{1.1}\right)$ memiliki nilai $0.738,\left(x_{1.2}\right)$ memiliki nilai $0.875,\left(x_{1.3}\right)$ memiliki nilai $0.843,\left(x_{1.6}\right)$ memiliki nilai 0.833 , sehingga memiliki korelasi terhadap konstruk Financial Attitude, dimana nilai korelasinya lebih tinggi daripada nilai korelasi terhadap Financial Behavior, Literasi Keuangan, dan Perencanaan Keuangan berdasarkan status Belum Menikah.

Tabel 2. Discriminant Validity Status Menikah

\begin{tabular}{llllll}
\hline Indikator & \multicolumn{3}{c}{ Konstruk } & \multirow{2}{*}{ Keterangan } \\
\cline { 2 - 5 } & $\begin{array}{l}\text { Financial } \\
\text { Attitude }\end{array}$ & $\begin{array}{l}\text { Financial } \\
\text { Behavior }\end{array}$ & $\begin{array}{l}\text { Literasi } \\
\text { Keuangan }\end{array}$ & $\begin{array}{l}\text { Perencanaan } \\
\text { Keuangan }\end{array}$ & \\
\hline X1.1 & 0.786 & 0.663 & 0.626 & 0.561 & Valid \\
\hline X1.2 & 0.798 & 0.691 & 0.527 & 0.535 & Valid \\
\hline X1.3 & 0.824 & 0.528 & 0.442 & 0.644 & Valid \\
\hline X1.6 & 0.817 & 0.620 & 0.475 & 0.342 & Valid \\
\hline Y1.1 & 0.762 & 0.911 & 0.590 & 0.497 & Valid \\
\hline Y1.3 & 0.629 & 0.755 & 0.451 & 0.202 & Valid \\
\hline Y1.4 & 0.244 & 0.611 & 0.246 & 0.138 & Valid \\
\hline Y2.3 & 0.665 & 0.522 & 0.788 & 0.251 & Valid \\
\hline Y2.4 & 0.421 & 0.505 & 0.793 & 0.121 & Valid \\
\hline Y3.1 & 0.249 & 0.254 & 0.664 & 0.243 & Valid \\
\hline Y3.2 & 0.565 & 0.360 & 0.148 & 0.736 & Valid \\
\hline Y3.4 & 0.496 & 0.304 & 0.283 & 0.755 & Valid \\
\hline
\end{tabular}

Indikator $\left(x_{1.1}\right)$ memiliki nilai $0.786,\left(x_{1.2}\right)$ memiliki nilai $0.798,\left(x_{1.3}\right)$ memiliki nilai $0.824,\left(x_{1.6}\right)$ memiliki nilai 0.817 sehingga memiliki korelasi terhadap konstruk Financial Attitude, dimana nilai korelasinya lebih tinggi daripada nilai korelasi terhadap Financial Behavior, Literasi Keuangan, dan Perencanaan Keuangan berdasarkan status Belum Menikah. 


\subsection{Evaluasi Realibilitas}

Untuk mengukur konsistensi alat ukur penelitian terutama untuk mengukur suatu konsep, maka digunakan uji reliabilitas. Selain itu dapat digunakan juga untuk menilai seberapa konsistensi jawaban dalam kuisioner maupun instrumen penelitian yang telah diisi oleh responden. Uji reliabilitas dapat dilihat dari nilai Crimbach's alpha dan nilai composive reliability. Apabila nilai Cronbach's alpha $>0.6$ dan composite reliability $>0.7$ maka dapat disimpulkan bahwa suatu item pernyataan telah reliable [22].

Tabel 3. Output Cronbach's Alpha dan Composite Reliability Status Belum Menikah

\begin{tabular}{lccc}
\hline Konstruk & $\begin{array}{c}\text { Cronbach's } \\
\text { Alpha }\end{array}$ & $\begin{array}{c}\text { Composite } \\
\text { Reliability }\end{array}$ & $\begin{array}{c}\text { Keterangan } \\
(\mathbf{C A}>\mathbf{0 . 6 0} \text { \& CR } \\
\mathbf{0 . 7 0 )}\end{array}$ \\
\hline $\begin{array}{l}\text { Financial Attitude } \\
\text { Financial Behavior }\end{array}$ & 0.840 & 0.894 & Reliabel \\
\hline $\begin{array}{l}\text { Literasi Keuangan } \\
\begin{array}{l}\text { Perencanaan } \\
\text { Keuangan }\end{array}\end{array}$ & 0.696 & 0.826 & Reliabel \\
\hline
\end{tabular}

Berdasarkan Tabel 3 semua konstruk berdasarkan status Belum Menikah dinyatakan reliabel karena memiliki nilai $\mathrm{CA}>0.60$ dan nilai $\mathrm{CR}>0.70$.

Tabel 4. Output Cronbach's Alpha dan Composite Reliability Status Menikah

\begin{tabular}{llcc}
\hline \multicolumn{1}{c}{ Konstruk } & $\begin{array}{c}\text { Cronbach's } \\
\text { Alpha }\end{array}$ & $\begin{array}{c}\text { Composite } \\
\text { Reliability }\end{array}$ & $\begin{array}{c}\text { Keterangan } \\
(\mathbf{C A}>\mathbf{0 . 6 0} \text { \& CR } \\
\mathbf{0 . 7 0})\end{array}$ \\
\hline Financial Attitude & 0.821 & 0.881 & Reliabel \\
\hline Financial Behavior & 0.666 & 0.809 & Reliabel \\
\hline $\begin{array}{l}\text { Literasi Keuangan } \\
\begin{array}{l}\text { Perencanaan } \\
\text { Keuangan }\end{array}\end{array}$ & 0.644 & 0.794 & Reliabel \\
\hline
\end{tabular}

Berdasarkan Tabel 4, semua konstruk berdasarkan status Menikah dinyatakan reliabel karena memiliki nilai $\mathrm{CA}>0.60$ dan nilai $\mathrm{CR}>0.70$.

\subsection{Goodness of Fit Model.}

Relevansi prediksi ( $Q$-square) yang berfungsi untuk memvalidasi model yang ada. Hasil $Q$-square dinyatakan baik jika nilainya sebesar $>0.5$, hal ini berarti model memiliki relevansi prediksi. Namun apabila nilai $Q$-square $\leq 0$ mengartikan bahwa kurangnya relevansi pada model tersebut. Hasil nilai $Q$-square adalah:

$$
Q^{2}=1-\left(1-R_{1}^{2}\right)\left(1-R_{2}^{2}\right)\left(1-R_{3}^{2}\right)
$$

Berdasarkan Persamaan (2) maka nilai $Q^{2}$ untuk masing-masing model adalah 0.076 untuk yang belum menikah dan 0.612 untuk yang telah menikah.

\subsection{Uji Hipotesis.}

Uji yang digunakan dalam penelitian ini yaitu statistiik $\mathrm{t}$ atau uji $\mathrm{t}$, dimana nilai $\mathrm{t}$-tabel untuk melihat taraf signifikansi adalah sebesar $5 \%=1,96 \%$. Hipotesis penelitian dinyatakan signifikan apabila nilai t-statistik $>1,96$. Pengujian hipotesis yang digunakan yaitu nilai Path Coefficients alam PLS. Adapun hasil output Path Coefficients pada PLS bootstrapping adalah sebagai berikut: 


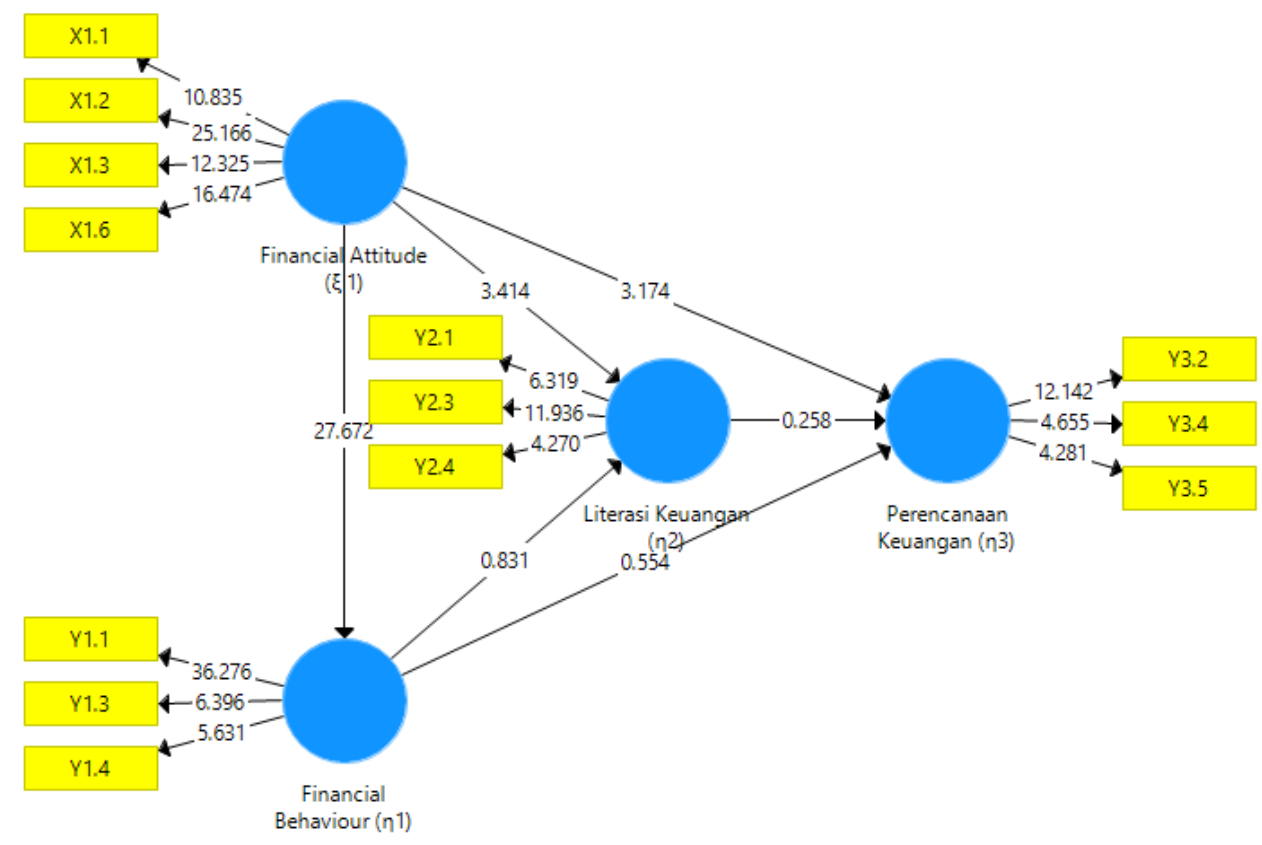

Gambar 7. Diagram Jalur Status Belum Menikah Setelah Bootstrapping

Berdasarkan hasil output Path Coefficient pada Gambar 7, terdapat tiga hubungan konstruk yang signifikan yaitu financial attitude terhadap financial behavior, financial attitude terhadap literasi keuangan, dan financial attitude terhadap perencanaan keuangan.

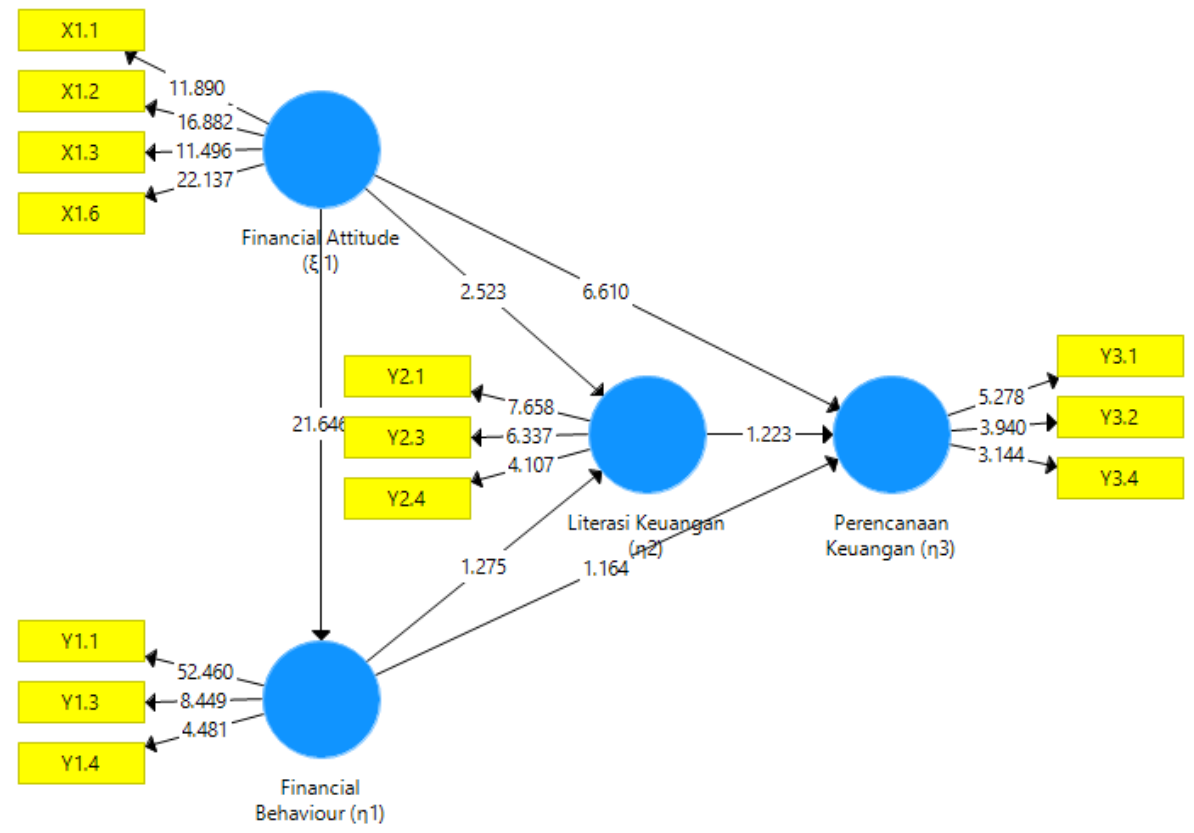

Gambar 8. Diagram Jalur Status Menikah Setelah Bootstrapping

Berdasarkan hasil output Path Coefficient di atas, terdapat tiga hubungan konstruk yang signifikan yaitu financial attitude terhadap financial behavior, financial attitude terhadap literasi keuangan, dan financial attitude terhadap perencanaan keuangan.

\section{7 Analisis Data Uji Beda (Independent Sample t-Test)}

Pada penelitian ini digunakana software SPSS untuk pengujian Independent Sample t-Test. 
Tabel 5. Hasil Independent Samples Test

\begin{tabular}{|c|c|c|c|c|c|c|c|c|c|c|}
\hline & & \multicolumn{4}{|c|}{$\begin{array}{l}\text { Levene's Test } \\
\text { for Equality of } \\
\text { Variances }\end{array}$} & \multicolumn{3}{|c|}{ t-test for Equality of Means } & & \\
\hline & & \multirow[t]{2}{*}{$\mathbf{F}$} & \multirow[t]{2}{*}{ Sig. } & \multirow[t]{2}{*}{$\mathbf{T}$} & \multirow[t]{2}{*}{ df } & \multirow[t]{2}{*}{$\begin{array}{l}\text { Sig. } \\
\text { tailed) }\end{array}$} & \multirow[t]{2}{*}{$\begin{array}{l}\text { 2-Mean } \\
\text { Difference }\end{array}$} & \multicolumn{3}{|c|}{$\begin{array}{c}\text { Std. Error95\% Confidence } \\
\text { Difference Interval of the } \\
\text { Difference }\end{array}$} \\
\hline & & & & & & & & & Lower & Upper \\
\hline \multirow[t]{2}{*}{$\begin{array}{l}\text { Perencanaan } \\
\text { keuangan }\end{array}$} & $\begin{array}{l}\text { Equal variances } \\
\text { assumed }\end{array}$ & .670 & .415 & -.316 & 118 & .753 & -.10000 & .31675 & -.72725 & .52725 \\
\hline & $\begin{array}{l}\text { Equal variances } \\
\text { not assumed }\end{array}$ & & & -.316 & 115.778 & .753 & -.10000 & .31675 & -.72737 & .52737 \\
\hline
\end{tabular}

Berdasarkan Tabel 5, maka dapat disimpulkan bahwa tidak ada perbedaan antara perencanaan keuangan status belum menikah dan perencanaan keuangan status menikah. Hal ini ditunjukkan dari hasil sig (2-tailed) perencanaan keuangan status belum menikah dan perencanaan keuangan status menikah sebesar $0.753>0.5$.

\subsection{Pembahasan.}

Hasil uji hipotesis (H1) diketahui bahwa financial attitude berpengaruh terhadap financial behavior berdasarkan status belum menikah dan status menikah. Sikap keuangan seseorang dapat membentuk kebiasaan untuk menyimpan, menggunakan, dan melakukan pemborosan terhadap uang yang dimiliki. Hal ini juga berpengaruh terhadap masalah keuangan yang dihadapi, seperti pada seseorang yang berstatus belum menikah cenderung memiliki pengeluaran yang belum terlalu banyak namun telah memiliki perencanaan dan pengelolaan keuangan yang baik di masa depan. Perilaku keuangan seseorang timbul dari sikap keuangan yang dimilikinya. Oleh karena itu seseorang berstatus menikah dengan adanya tunggakan pembayaran tagihan dan persiapan keperluan tidak terduga, menjadi hal yang penting adanya sikap keuangan yang baik, agar terhindar dari kesalahan keputusan keuangan yang mungkin terjadi. Hal ini sesuai dengan penelitian yang sebelumnya dihasilkan oleh [23] dan [11].

Kemudian hasil pengujian hipotesis (H2) membuktikan bahwa financial attitude berpengaruh signifikan terhadap literasi keuangan berdasarkan status belum menikah dan status menikah. Financial attitude sejalan dengan unsur pengetahuan keuangan, dimana sikap keuangan diartikan sebagai sesuatu yang erat kaitannya dengan permsasalahan-permasalahan keuangan pribadi ditinjau secara psikologis. Sikap keuangan yang tepat akan diikuti dengan pengetahuan mengenai keuangan yang baik pula. Hal ini didasari dari kemampuan seseorang untuk mengelola (merencanakan, menganggarkan, memeriksa, mengelola, mengendalikan, mencairkan, dan menyimpan) dana keuangan yang merupakan bentuk pemahaman seseorang terhadap ilmu keuangan. Hasil penelitian tersebut relevan dengan yang dikemukakan oleh [12] serta [11].

Hipotesis berikutnya (H3) menunjukkan bahwa financial attitude berpengaruh signifikan terhadap perencanaan keuangan. Cara terbaik untuk memprediksi kondisi ekonomi menurut kesepakatan para ahli adalah dengan memperhatikan sikap dan perilaku masyarakat terhadap keuangan [13]. Cara seseorang menyikapi uang dapat memunculkan sifat dan perilaku tidak puas, dendam, cemas, dan perilaku antisosial, oleh karena itu sikap seseorang terhadap uang sangat berpengaruh dalam penggunaan uang dan perencanaan keuangan yang dilakukan. Seseorang dengan status belum menikah yang memiliki sikap keuangan yang baik, cenderung berfikir bahwa merencanaan keuangan penting untuk dilakukan Sebab dengan beban-beban yang belum terlalu banyak maka seseorang tersebut dapat memaksimalkan pendapatan yang dimilikinya.

Hasil uji hipotesis (H4) financial behavior tidak berpengaruh signifikan terhadap literasi keuangan. Seseorang yang dihadapkan pada kondisi kurangnya pengetahuan yang baik tentang keuangan dan manajemen keuangan pribadi yang baik, maka seseorang cenderung dapat menggunakan hutang untuk memenuhi keinginannya. Hal ini menunjukkan bahwa pengetahuan seseorang terhadap keuanganlah yang dapat mengubah perilaku seseorang terhadap pengambilan kebijakan tentang keuangan. Seseorang yang belum menikah akan cenderung berprilaku mengikuti trend yang ada, ini dikarenakan seseorang tersebut hanya memenuhi kebutuhan untuk dirinya sendiri. Sehingga seseorang dengan status belum menikah merasa belum adanya kewajiban untuk menabung maupun menginvestasikan kekayaannya. Pada akhirnya, akan meyebabkan rendahnya tingkat konsumtif seseorang karena keputusan finansial yang lebih mengutamakan 
efisiensi. Hal ini juga dikarenakan mereka memiliki tuntutan untuk lebih tepat dalam mengambil keputusan demi kebaikan keluarganya. Penelitian ini sesuai dengan penelitian [24].

Kemudian hipotesis (H5) menghasilkan bahwa financial behaviour tidak berpengaruh signifikan terhadap perencanaan keuangan. Hal ini sesuai dengan penelitian [25]. Perilaku tidak dapat mencerminkan kebiasaaan seseorang dalam merencanakan keuangan pribadi karena sebaliknya seseorang akan memiliki financial literacy ketika sudah memiliki financial knowledge yang baik juga. Namun berbeda dengan penelitian [26] yang menyatakan financial behavior berpengaruh positif dan signifikan terhadap perencanaan keuangan. Seseorang dengan status menikah cenderung memiliki kebiasaan untuk menggunakan uangnya untuk kebutuhan bukan keinginan saja, hal ini dikarenakan beban-beban yang harus ditanggung. Seseorang dengan status menikah akan lebih mementingkan pengeluaran berdasarkan kebutuhan keluarganya dan berfokus pada pemenuhan kebutuhan yang ada. Persiapan dana untuk masa pensiun juga menjadi salah satu faktor pentingnya perencaan keuangan dan pengelolaan keuangan keluarga.

Hasil Uji hipotesis (H6) literasi keuangan menghasilkan pengaruh tidak signifikan terhadap perencanaan keuangan. Hasil ini sejalan dengan yang dihasilkan oleh [27]. Seseorang dengan status belum menikah dengan pemahaman mengenai pentingnya perencanaan keuangan, belum tentu miliki perencanaan keuangan yang baik pula. Hal ini dikarenakan seseorang dengan status belum menikah merasa bahwa belum adanya kewajiban untuk mempersiapkan dana dimasa tuanya, namun mengetahui pentinya saving dan investasi. Seseorang dengan status menikah cenderung lebih fokus dalam pemenuhan kebutuhan jangka pendek karena merasa pemenuhan kebutuhan-kebutuhan keluarganya belum maksimal. Oleh karena itu mereka belum benar-benar merasa penting utnuk mempersiapkan pendanaan dimasa tua sejak dini. Namun berbeda dengan penelitian [28], [29] dan [30], tingkat literasi seseorang berpengaruh terhadap perencanaan keuangan yang dimilikinya. Seseorang dengan pengetahuan keuangan yang buruk dapat menyebabkan seseorang tersebut terlibat hutang dan ini disebabkan kurangnya pengetahuan dalam merencanakan keuangannya.

Terakhir, hasil uji beda perencanaan keuangan status belum menikah dan keuangan status menikah menunjukkan tidak adanya perbedaan perencanaan keuangan apapun status pernikahannya (menikah maupun belum menikah). Hasil ini relevan dengan yang dikemukakan oleh [31] bahwa status perkawinan seseorang tidak memiliki perbedaan pada tingkat literasi keuangan termasuk di dalamnya dalam perencanaan keuangannya. Pada status menikah memang memiliki fokus paling besar, dimana seseorang tersebut dituntut untuk memenuhi kebutuhan keluarga dengan layak dan mempersiapkan berbagai macam kemungkinan pengeluaran yang dapat terjadi. Namun seseorang yang belum menikah juga memiliki tuntutan memenuhi kebutuhan dirinya, keinginan untuk dirinya sendiri dan persiapan akan pengeluaran dimasa yang akan datang. Oleh karena itu dua material status tersebut dituntut untuk memiliki perencanaan keuangan dan mengatur pengeluaran mereka dengan baik

\section{KESIMPULAN}

Setiap orang diharuskan untuk memiliki perencanaan keuangan yang baik tanpa melihat status pernikahannya. Hasil penelitian ini menunjukkan bahwa:

1. financial attitude memberikan pengaruh signifikan terhadap financial behavior, financial attitude memberikan pengaruh signifikan terhadap literasi keuangan, financial attitude berpengaruh signifikan terhadap perencanaan keuangan, financial behavior memberikan pengaruh tidak signifikan terhadap literasi keuangan, financial behavior berpengaruh tidak signifikan terhadap perencanaan keuangan, dan literasi keuangan berpengaruh tidak signifikan terhadap perencanaan keuangan untuk status belum menikah

2. financial attitude berpengaruh signifikan terhadap literasi keuangan, financial attitude berpengaruh signifikan terhadap perencanaan keuangan, financial behavior berpengaruh tidak signifikan terhadap literasi keuangan, financial behavior berpengaruh tidak signifikan terhadap perencanaan keuangan, dan literasi keuangan berpengaruh tidak signifikan terhadap perencanaan keuangan.

Hasil Uji Independent Sampel t-test perencanaan keuangan status belum menikah dan perencanaan keuangan status menikah tidak memiliki perbedaan. Hal tersebut menunjukkan bahwa material status menikah dan belum menikah yang dimiliki seseorang tidak menjamin seseorang tersebut memiliki perencanaan keuangan yang baik. 


\section{DAFTAR PUSTAKA}

[1] OJK, "Survei Nasional Literasi dan Inklusi Keuangan 2016 (National Literacy and Financial Inclusion Survey 2016),” Surv. Rep., 2016.

[2] BPS-Statistics Indonesia, "Statistical Yearbook of Indonesia 2017," BPS-Statistics Indones., 2017.

[3] OJK, "OJK: Indeks Literasi Dan Inklusi Keuangan Meningkat," Ojk, 2017.

[4] N. Garg and S. Singh, "Financial literacy among youth," International Journal of Social Economics. 2018, doi: 10.1108/IJSE11-2016-0303.

[5] J. Hastings and L. Tejeda-Ashton, "Financial Literacy, Information, and Demand Elasticity: Survey and Experimental Evidence from Mexico," Natl. Bur. Econ. Res., 2008, doi: 10.3386/w14538.

[6] A. Lusardi and O. Mitchelli, "Financial literacy and retirement preparedness: Evidence and implications for financial education," Bus. Econ., 2007, doi: 10.2145/20070104.

[7] N. Novandriani and K. Moeliono, "Analisis Tingkat Literasi Keuangan Pada Dosen Universitas Telkom Tahun 2016," J. Ekon. Bisnis Entrep., 2017.

[8] S. P. Robbins and T. A. Judge, Perilaku organisasi edisi ke-12. 2008.

[9] A. Furnham, "Many sides of the coin: The psychology of money usage," Pers. Individ. Dif., 1984, doi: 10.1016/01918869(84)90025-4.

[10] F. Khairani and M. F. Alfarisi, “Analisis Pengaruh Financial Attitude, Financial Knowledge, Pendidikan Orang Tua Dan Parental Income Terhadap Financial Management Behavior Pada Mahasiswa S1 Universitas Andalas ...,” J. Ilm. Mhs. Ekon. Manaj., 2019.

[11] M. Ameliawati and R. Setiyani, "The Influence of Financial Attitude, Financial Socialization, and Financial Experience to Financial Management Behavior with Financial Literacy as the Mediation Variable," KnE Soc. Sci., 2018, doi: 10.18502/kss.v3i10.3174.

[12] J. Diniaty, "Pengaruh Karakteristik Demografi dan Karakteristik Personalitas terhadap Tingkat Literasi Keuangan Mahasiswa Program Studi Manajemen Universitas Kristen Maranatha," Undergrad. thesis, Univ. Kristen Maranatha, 2016.

[13] E. Németh and B. Zsótér, "Personality, Attitude and Behavioural Components of Financial Literacy: A Comparative Analysis," J. Econ. Behav. Stud., 2017, doi: 10.22610/jebs.v9i2.1649.

[14] K. M. Brown and R. A. Laschever, "When they're sixty-four: Peer effects and the timing of retirement," Am. Econ. J. Appl. Econ., 2012, doi: 10.1257/app.4.3.90.

[15] A. H. Manurung, “Teori Perilaku Keuangan ( Behaviour Finance ),” Econ. Manag., 2012, doi: 10.1016/j.tics.2009.08.002.

[16] H. CHEN, “An analysis of personal financial literacy among college students," Financ. Serv. Rev., 1998, doi: 10.1016/s10570810(99)80006-7.

[17] A. N. Yushita, "PENTINGNYA LITERASI KEUANGAN BAGI PENGELOLAAN KEUANGAN PRIBADI," Nominal, Barom. Ris. Akunt. dan Manaj., 2017, doi: 10.21831/nominal.v6i1.14330.

[18] J. R. Kapoor, L. R. Dlabay, and R. J. Hughes, Business and Personal Finance. 2007.

[19] O. S. Mitchell and A. Lusardi, "Financial Literacy and Planning: Implications for Retirement Well-being," in Financial Literacy: Implications for Retirement Security and the Financial Marketplace, 2011.

[20] BPS, "Perkawinan Usia Anak di Indonesia," Br. J. Psychiatry, 2017.

[21] G. D. Garson, Partial Least Squares: Regression \& Structural Equation Models (3th Ed.). 2016.

[22] I. Ghozali, Aplikasi Analisis Multivariate dengan Program SPSS (Edisi Ketiga), 3rd ed. Semarang: Semarang: Badan Penerbit Universitas Diponegoro, 2005.

[23] I. Herdjiono and L. A. Damanik, "Pengaruh Financial Attitude,Financial Knowledge, Parental Income Terhadap Financial Management Behavior," J. Manaj. Teor. dan Ter. J. Theory Appl. Manag., 2016, doi: 10.20473/jmtt.v9i3.3077.

[24] A. Ansong and M. A. Gyensare, "Determinants of University Working-Students' Financial Literacy at the University of Cape Coast, Ghana," Int. J. Bus. Manag., 2012, doi: 10.5539/ijbm.v7n9p126.

[25] Yuliani, L. L. Fuadah, and Taufik, "Moderating Influence of Gender on the Association Between Financial Attitude, Financial Behavior, Financial Knowledge, and Financial Literacy," 2020, doi: 10.2991/aebmr.k.200520.059.

[26] C. A. Robb and A. S. Woodyard, "Financial knowledge and best practice behavior," J. Financ. Couns. Plan., 2011.

[27] L. Susdiani, "Pengaruh Financial Literacy dan Financial Experience Terhadap Perilaku Perencanaan Investasi PNS Di Kota Padang," J. Pembang. Nagari, 2017.

[28] S. J. Huston, “296 THE JOURNAL OF CONSUMER AFFAIRS Measuring Financial Literacy,” J. Consum. Aff., 2010.

[29] A. S. Mendari and F. Soejono, "Hubungan Tingkat Literasi Dan Perencanaan Keuangan," MODUS J., vol. Vol. 31 (2, no. 2, pp. 227-240, 2019, doi: https://doi.org/10.24002/modus.v31i2.2412.

[30] T. H. Boon, H. S. Yee, and H. W. Ting, "Financial literacy and personal financial planning in Klang Valley, Malaysia," Int. J. Econ. Manag., 2011.

[31] K. J. Inder et al., "Determinants of suicidal ideation and suicide attempts: Parallel cross-sectional analyses examining geographical location,” BMC Psychiatry, 2014, doi: 10.1186/1471-244X-14-208. 
